\title{
Potential immune-modulatory effects of wheat phytase on the performance of a mouse macrophage cell line, Raw 264.7, exposed to long-chain inorganic polyphosphate
}

\author{
Jeongmin $\mathrm{An}^{1}$ and Jaiesoon $\mathrm{Cho}^{1, *}$
}

\begin{abstract}
* Corresponding Author: Jaiesoon Cho Tel: +82-2-450-3375, Fax: +82-2-455-1044 E-mail: chojs70@konkuk.ac.kr
\end{abstract}

${ }^{1}$ Department of Animal Science and Technology, Konkuk University, Seoul 05029, Korea

ORCID

Jeongmin An

https://orcid.org/0000-0002-2357-0941

Jaiesoon Cho

https://orcid.org/0000-0002-4511-8032

Submitted Feb 5, 2020; Revised Apr 3, 2020; Accepted Apr 27, 2020
Objective: This experiment was conducted to find out the immunological effects of wheat phytase when long-chain inorganic polyphosphate (polyP) treated with wheat phytase was added to a macrophage cell line, Raw 264.7, when compared to intact long-chain polyP.

Methods: Nitric oxide (NO) production of Raw 264.7 cells exposed to P700, a long-chain polyP with an average of 1,150 phosphate residues, treated with or without wheat phytase, was measured by Griess method. Phagocytosis assay of P700 treated with or without phytase in Raw 264.7 cells was investigated using neutral red uptake. The secretion of tumor necrosis factor $\alpha$ (TNF- $\alpha$ ) by Raw 264.7 cells with wheat phytase-treated P700 compared to intact P700 was observed by using Mouse TNF- $\alpha$ enzyme-linked immunosorbent assay kit.

Results: P700 treated with wheat phytase effectively increased NO production of Raw 264.7 cells by $172 \%$ when compared with intact P700 at $12 \mathrm{~h}$ exposure. At $5 \mathrm{mM}$ of P700 concentration, wheat phytase promoted NO production of macrophages most strongly. P700, treated with wheat phytase, stimulated phagocytosis in macrophages at $12 \mathrm{~h}$ exposure by about 1.7-fold compared to intact P700. In addition, P700 treated with wheat phytase effectively increased in vitro phagocytic activity of Raw 264.7 cells at a concentration above $5 \mathrm{mM}$ when compared to intact P700. P700 dephosphorylated by wheat phytase increased the release of TNF- $\alpha$ from Raw 264.7 cells by $143 \%$ over that from intact P700 after $6 \mathrm{~h}$ exposure. At the concentration of $50 \mu \mathrm{M}$ P700, wheat phytase increased the secretion of cytokine, TNF- $\alpha$, by $124 \%$ over that from intact P700.

Conclusion: In animal husbandry, wheat phytase can mitigate the long-chain polyP causing damage by improving the immune capabilities of macrophages in the host. Thus, wheat phytase has potential as an immunological modulator and future feed additive for regulating immune responses caused by inflammation induced by long-chain polyP from bacterial infection.

Keywords: Animal Husbandry; Immunological Effects; Long-chain Inorganic Polyphosphate; Macrophage; Wheat Phytase

\section{INTRODUCTION}

Phytase is a type of phosphatase that hydrolyzes phytin [1]. Phytin is a storage compound of phosphate in large quantities in plant seeds and an anti-nutritional factor [1]. The phosphatases are classified as acid or alkaline phytase according to the optimum $\mathrm{pH}$, and depending on the initial position of hydrolysis of the phytate, they are classified as 3-phytase, 6-phytase, or 5-phytase [2]. According to their catalytic mechanisms, phosphatases are classified as histidine-acid phosphatases (HAPs), purple-acid phosphatases, cysteine phosphatases, or $\beta$-propeller phytases (BPPhys) [2]. To date, all commercially available phytase belongs to the HAP group, and the fungal-derived phytase, which has been widely 
used as a feed additive, is affiliated to the HAPs family. In this study, however, wheat phytase is regarded as multiple inositol polyphosphate phosphatase (formerly known as inositol 1,3,4,5-tetrakisphosphate 3-phosphatase), which forms a separate group within the HAP group [2,3]. It has enzymatic substrate hydrolysis properties different from those of fungal phytase [4].

A combination of ten or more inorganic phosphate $(\mathrm{Pi})$ residues by high-energy phosphoanhydride bonds, such as ATP, is called inorganic polyphosphate (polyP), and this linear polymer is found in bacteria, fungi, and some higher eukaryotes [5]. In particular, the long-chain inorganic polyphosphate that is linked to about 200 or more $\mathrm{Pi}$ is used in bacterial expression and in the storage of phosphates [6]. It is also required for virulence and survival in many bacteria $[7,8]$. The gene $(p p k)$ that encodes the polyphosphate kinase (PPK), the enzyme responsible for the biosynthesis of polyP from $\mathrm{Pi}$, is important for the long-term survival and virulence of many pathogens, including Shigella and Salmonella spp. [6,7]. Thus, the inactivation of $p p k$ reduces host invasibility and intracellular survival of Salmonella enterica serovar typhimurium (S. typhimurium) in epithelial cells and macrophages [9]. S. typhimurium is a major bacteria of gastrointestinal inflammation caused by food in humans, in poultry it infiltrates into the intestinal tissue and stays there, but in pigs it acts as causative bacteria of chronic enteritis [9]. Recently, the appearance of S. typhimurium DT 104-resistant bacteria, caused by the increase of overused antibiotics, made it more important to prevent livestock diseases [9]. Campylobacter jejuni is also a major cause of bacterial diarrhea around the world [10]. According to immunological studies, nearly 90 percent of poultry in the United States suffer from C. jejuni. Like Salmonella, C. jejuni needs polyP to maintain its virulence [10]. Thus, modulating the long-chain polyP metabolic pathway can effectively control those bacterial infections in the animal industry. However, previous research mainly focused on short- and medium-chain polyP as a substrate, so little is known about long-chain polyP as substrates [11].

Wheat phytase, a type of exopolyphosphatase (PPX), can hydrolyze polyP into ortho-inorganic phosphate because of its strong, non-specific dephosphorylation property [4]. Therefore, the dephosphorylation of pathogen-derived polyP by wheat phytase changes the metabolism of polyP in pathogens, which might lead to stimulating immune response in immune cells. Interestingly, some studies have shown that polyP, containing 1,150 phosphate residues (P700), similar in size to that in bacteria, combines with high-mobility group box protein-1, a pro-inflammatory cytokine, to elicit a strong inflammatory response in endotheliocytes $[12,13]$. P700 is reported to induce inflammatory responses in vascular endothelial cells [14]. Thus, wheat phytase might affect the combination of P700 and cytokine and their immune re- sponse. To date, however, the reports on polyP have been mainly about endothelial cells, and there have been no reports on macrophages, a typical immune cell. So the purpose of this study is to explore the characteristics of wheat phytase as an immunological modulator in macrophages in response to long-chain polyP, such as P700 substrate that can be released through infection of bacteria.

\section{MATERIALS AND METHODS}

\section{Reagents and cell culture}

Long-chain polyP, P700 with average 1,150 Pi residues was procured from Kerafast (Boston, MA, USA). Wheat phytase and Griess reagent were purchased from Sigma-Aldrich. Cymax mouse tumor necrosis factor a (TNF- $\alpha$ ) enzymelinked immunosorbent assay (ELISA) kit and Raw 264.7 cell (mouse macrophage cell line) were obtained from $\mathrm{Ab}$ Frontier and Korean Cell Line Bank, respectively. These cells were maintained in Dulbecco's modified eagle medium (Gibco Life Technologies, Waltham, MA, USA) containing 10\% fetal bovine serum and $1 \%$ penicillin-streptomycin (Gibco Life Technologies, USA), and were cultured in a humidified incubator at $37^{\circ} \mathrm{C}$ with $5 \% \mathrm{CO}_{2}$.

\section{Effect of long-chain inorganic polyphosphate treated with wheat phytase on nitric oxide production of Raw 264.7 cells}

At first, we seeded Raw 264.7 cells onto 96-well plates at a concentration of $2 \times 10^{4}$ cells per well and cultured them until $80 \%$ confluency. P700 $(500 \mathrm{mM})$ was incubated at $37^{\circ} \mathrm{C}$ for $4 \mathrm{~h}$ with or without wheat phytase $(42.9 \mathrm{mU} / \mathrm{mL})$. After the incubation, we applied aliquots $(10 \mu \mathrm{L})$ of the reaction mixture $(0.1 \mathrm{~mL})$ to the cells at $37^{\circ} \mathrm{C}$ for $1,6,12$, and $24 \mathrm{~h}$ in the $\mathrm{CO}_{2}$ incubator. In addition, we treated aliquots $(10 \mu \mathrm{L})$ of the reaction mixture containing different concentrations of P700 with or without wheat phytase $(42.9 \mathrm{mU} / \mathrm{mL})$ to the cells with each final concentration of $0.1,1,2.5,5,25$, and 50 $\mathrm{mM}$ P700 at $37^{\circ} \mathrm{C}$ for $12 \mathrm{~h}$ in the $\mathrm{CO}_{2}$ incubator. The levels of nitric oxide (NO) released into the culture media were measured at optical density at $540 \mathrm{~nm}\left(\mathrm{OD}_{540 \mathrm{~nm}}\right)$ using the Griess method [15].

\section{Effect of long-chain inorganic polyphosphate treated} with wheat phytase on phagocytic activity of Raw 264.7 cells

Raw 264.7 cells were initially seeded onto 96-well plates at a concentration of $2 \times 10^{4}$ cells per well and were cultured until $80 \%$ confluency. We did a phagocytic activity assay at $37^{\circ} \mathrm{C}$ for $4 \mathrm{~h}$ in $0.1 \mathrm{~mL}$ of a reaction mixture consisting of P700 with or without wheat phytase. We treated aliquots $(10 \mu \mathrm{L})$ of the reaction mixture containing $500 \mathrm{mM}$ P700 with or without wheat phytase $(42.9 \mathrm{mU} / \mathrm{mL})$ to the Raw 264.7 cells 
at $37^{\circ} \mathrm{C}$ for $1,6,12$, and $24 \mathrm{~h}$ in the $\mathrm{CO}_{2}$ incubator. In addition, we treated aliquots $(10 \mu \mathrm{L})$ of the reaction mixture made up of different concentrations of P700 with or without wheat phytase $(42.9 \mathrm{mU} / \mathrm{mL})$ to the cells with each final concentration of $0.1,1,2.5,5,25$, and $50 \mathrm{mM} \mathrm{P} 700$ at $37^{\circ} \mathrm{C}$ for $6 \mathrm{~h}$ in the $\mathrm{CO}_{2}$ incubator. Phagocytic activity was measured at $\mathrm{OD}_{540 \mathrm{~nm}}$ using neutral red uptake [16].

Effect of long-chain inorganic polyphosphate treated with wheat phytase on the release of TNF- $\alpha$ in Raw 264.7 cells

First of all, Raw 264.7 cells were initially seeded onto 96-well plates at a concentration of $2 \times 10^{4}$ cells per well and were cultured until $80 \%$ confluency. P700 $(1 \mathrm{mM})$ was incubated at $37^{\circ} \mathrm{C}$ for $4 \mathrm{~h}$ with or without wheat phytase $(42.9 \mathrm{mU} / \mathrm{mL})$, and aliquots $(10 \mu \mathrm{L})$ of the reaction mixture were added to the cells at $37^{\circ} \mathrm{C}$ for $0.5,1,3$, and $6 \mathrm{~h}$ in the $\mathrm{CO}_{2}$ incubator. In addition, we treated aliquots $(10 \mu \mathrm{L})$ of the reaction mixture containing different concentrations of P700 with or without wheat phytase $(42.9 \mathrm{mU} / \mathrm{mL})$ to the cells with each final concentration of $2,10,50$, and $100 \mu \mathrm{MP} 700$ at $37^{\circ} \mathrm{C}$ for $1 \mathrm{~h}$ in the $\mathrm{CO}_{2}$ incubator. The levels of TNF- $\alpha$ secreted into the culture media were assayed at $\mathrm{OD}_{450 \mathrm{~nm}}$ using a mouse TNF- $\alpha$ ELISA kit according to the manufacturer's instructions.

\section{Statistical analysis}

Statistical analysis was done by one-way ANOVA using PROC GLM (SAS 9.4, SAS Institute Inc, Cary, NC, USA) to test for significant differences between treatments with the
Duncan's multiple-range test. The probability levels used for statistical significance were $p<0.05$. The results are presented as the mean and standard error from three experiments.

\section{RESULTS}

Effect of long-chain inorganic polyphosphate treated with wheat phytase on nitric oxide production of Raw 264.7 cells

As shown in Figure 1, 2, P700 treated with wheat phytase increased NO production of Raw 264.7 cells more than did intact P700. At 12 h, compared with intact P700, P700 treated with wheat phytase promoted NO production of macrophages to approximately $172 \%$ (Figure 1 ). Wheat phytase promoted NO production most strongly at the $5 \mathrm{mM}$ concentration of P700 (Figure 2).

Effect of long-chain inorganic polyphosphate treated with wheat phytase on phagocytic activity of Raw 264.7 cells

P700 treated with wheat phytase stimulated phagocytosis of macrophages. At 6 h, P700 treated with wheat phytase displayed the maximal phagocytic activity of Raw 264.7 cells and at $12 \mathrm{~h}$, wheat phytase promoted phagocytosis of Raw 264.7 cells by about 1.7 -fold over that of the intact one (Figure 3). The phagocytosis of all P700 with wheat phytase at concentrations above $5 \mathrm{mM}$ of P700 was increased by more than 1.2-fold over that of the intact P700 (Figure 4).

\section{Effect of long-chain inorganic polyphosphate treated}

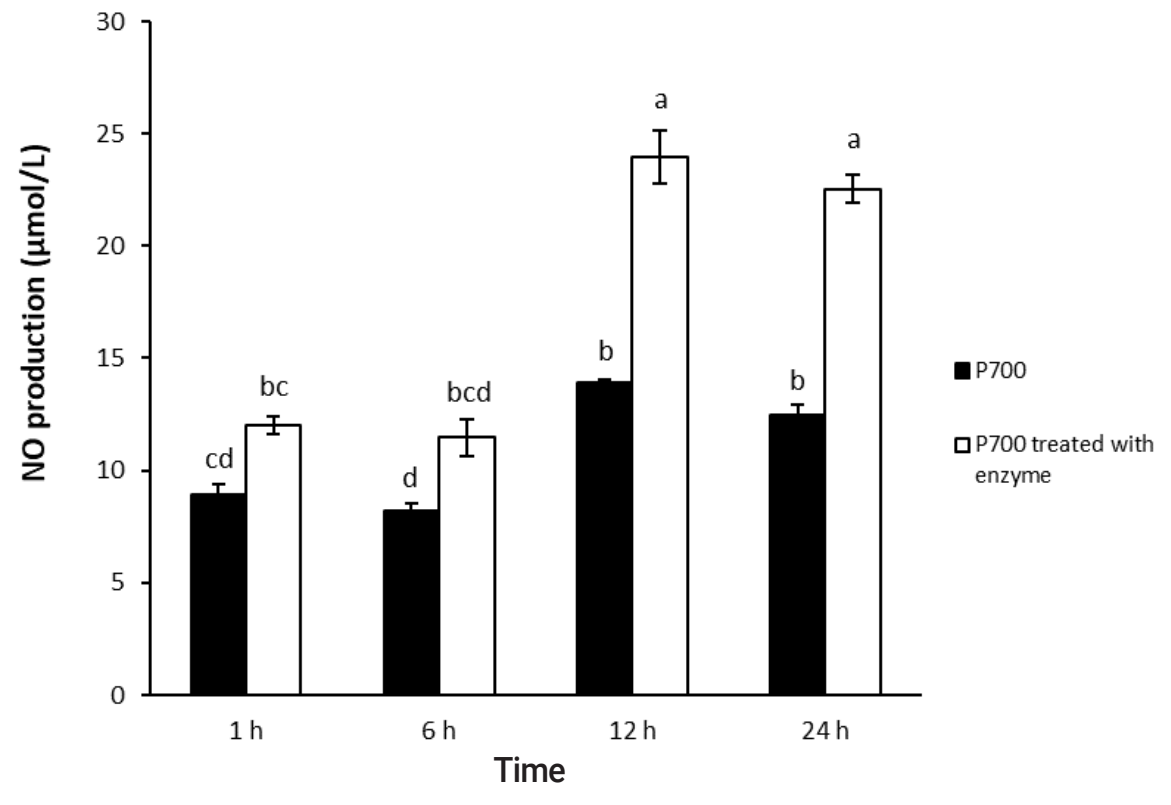

Figure 1. Nitric oxide production by Raw 264.7 macrophage cells exposed to long-chain inorganic polyphosphate treated with wheat phytase during different times. Data are expressed as the mean and standard error from three experiments. ${ }^{\text {a-d }}$ Means lacking common superscripts differ significantly $(p<0.05)$. 


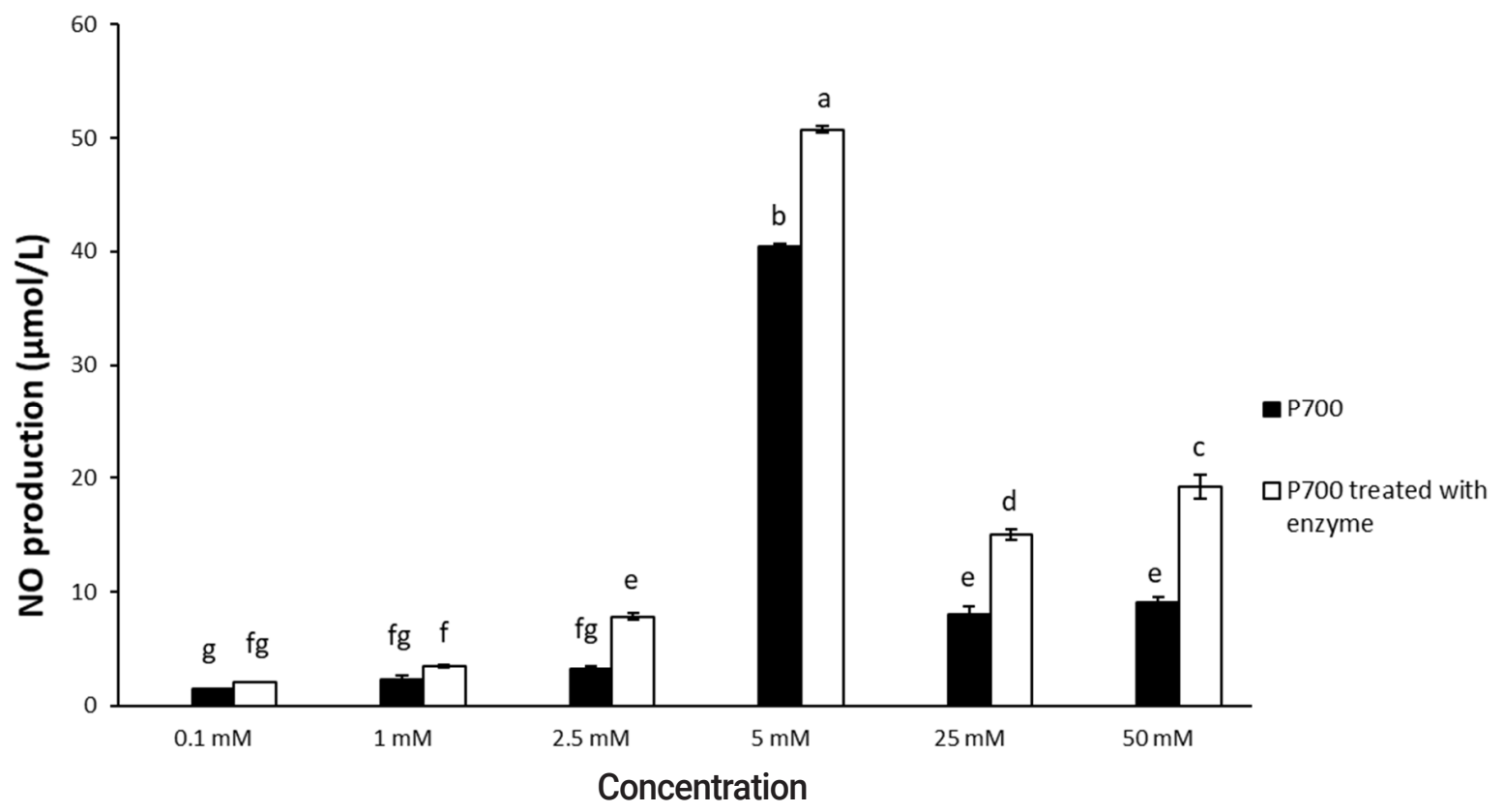

Figure 2. Nitric oxide production by Raw 264.7 macrophage cells exposed to various concentrations of long-chain inorganic polyphosphate treated with wheat phytase. Data are expressed as the mean and standard error from three experiments. ${ }^{\mathrm{a}-\mathrm{g}}$ Means lacking common superscripts differ significantly $(p<0.05)$

with wheat phytase on the release of TNF- $\alpha$ in Raw 264.7 cells

In a time-dependent manner, both intact P700 and P700 treated with wheat phytase increased TNF- $\alpha$ secretion from macrophage cell line of Raw 264.7 cells (Figure 5). In particular, the TNF- $\alpha$ release was increased by about $143 \%$ over that from intact P700 after $6 \mathrm{~h}$ of the exposure of P700 treated with wheat phytase. In addition, at the concentration of
$50 \mu \mathrm{M}$ P700, the wheat phytase increased the secretion of cytokine, TNF- $\alpha$, by $124 \%$ over that of the intact P700 (Figure 6).

\section{DISCUSSION}

In animal husbandry, long-chain polyP-mediated infection by pathogenic bacteria can be controlled by application of

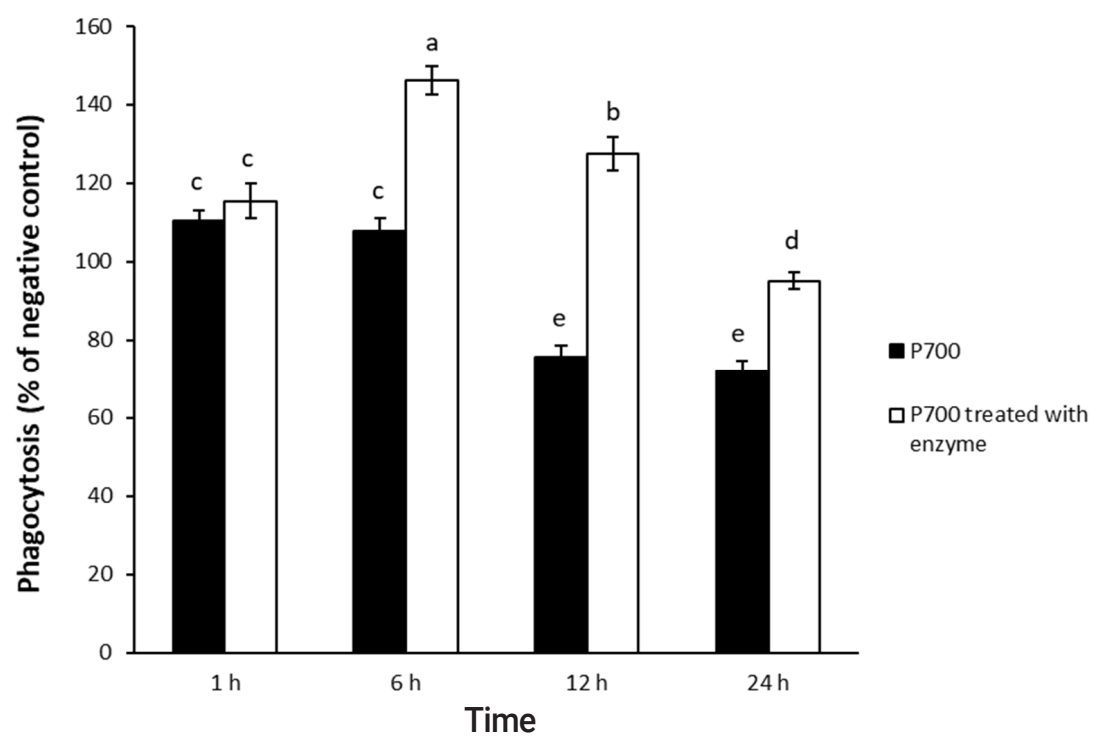

Figure 3. Phagocytic activity by Raw 264.7 macrophage cells exposed to long-chain inorganic polyphosphate treated with wheat phytase during different times. Data are expressed as the mean and standard error from three experiments. ${ }^{\text {ae }}$ Means lacking common superscripts differ significantly $(p<0.05)$. 


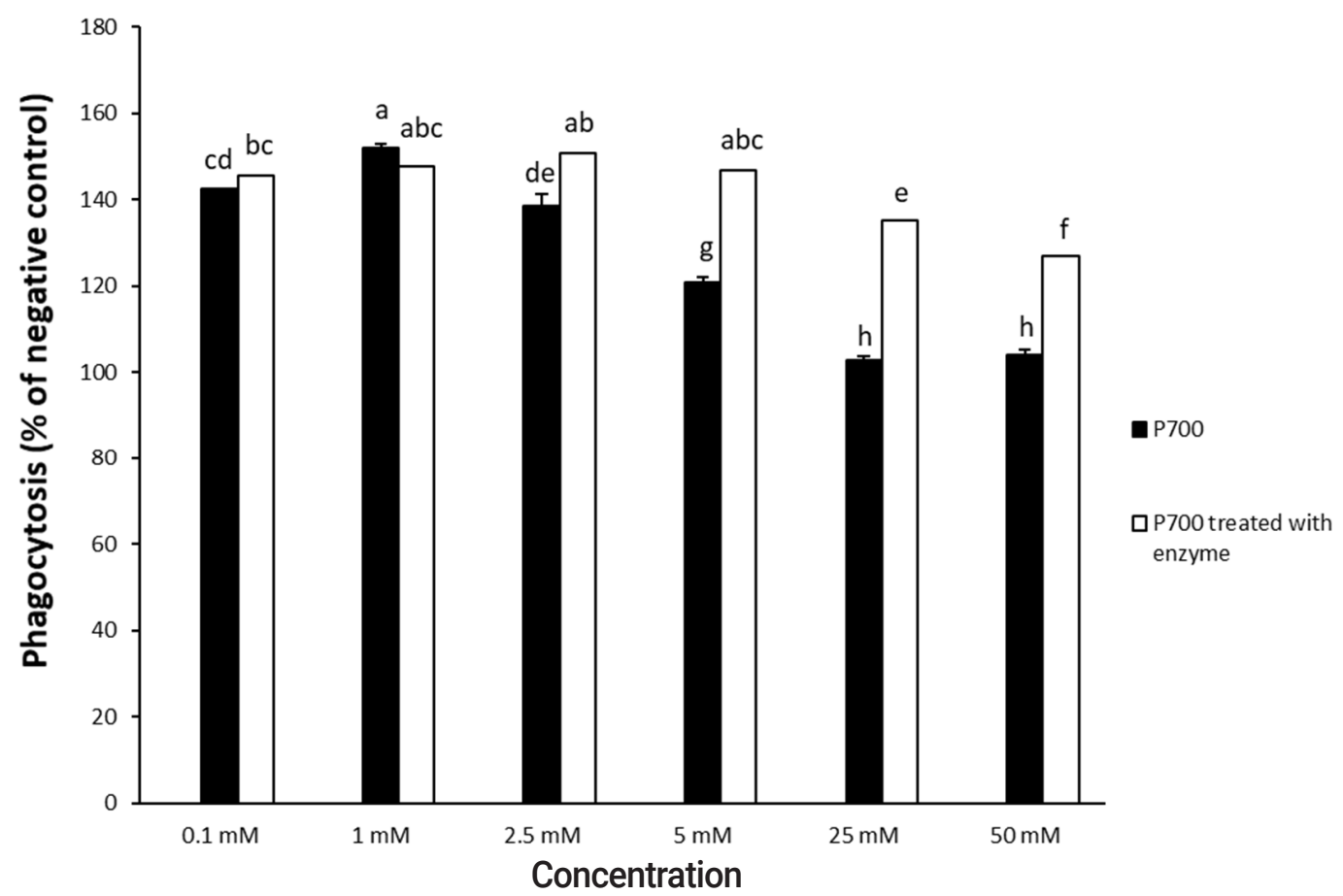

Figure 4. Phagocytic activity by Raw 264.7 macrophage cells exposed to various concentrations of long-chain inorganic polyphosphate treated with wheat phytase. Data are expressed as the mean and standard error from three experiments. ${ }^{\text {ath }}$ Means lacking common superscripts differ significantly $(p<0.05)$.

immune-modulatory supplements like probiotics, herbal and essential oil $[17,18]$. But they have only indirect effects on the targets and stimulate other immune cells in the body that may be obscurable [17]. The potential of wheat phytase as an effective immunological modulator is reported in terms of various immunological response assays in this study.

Nitric oxide, an important molecule that removes tumor cells and pathogenic microorganisms, regulates the activa-

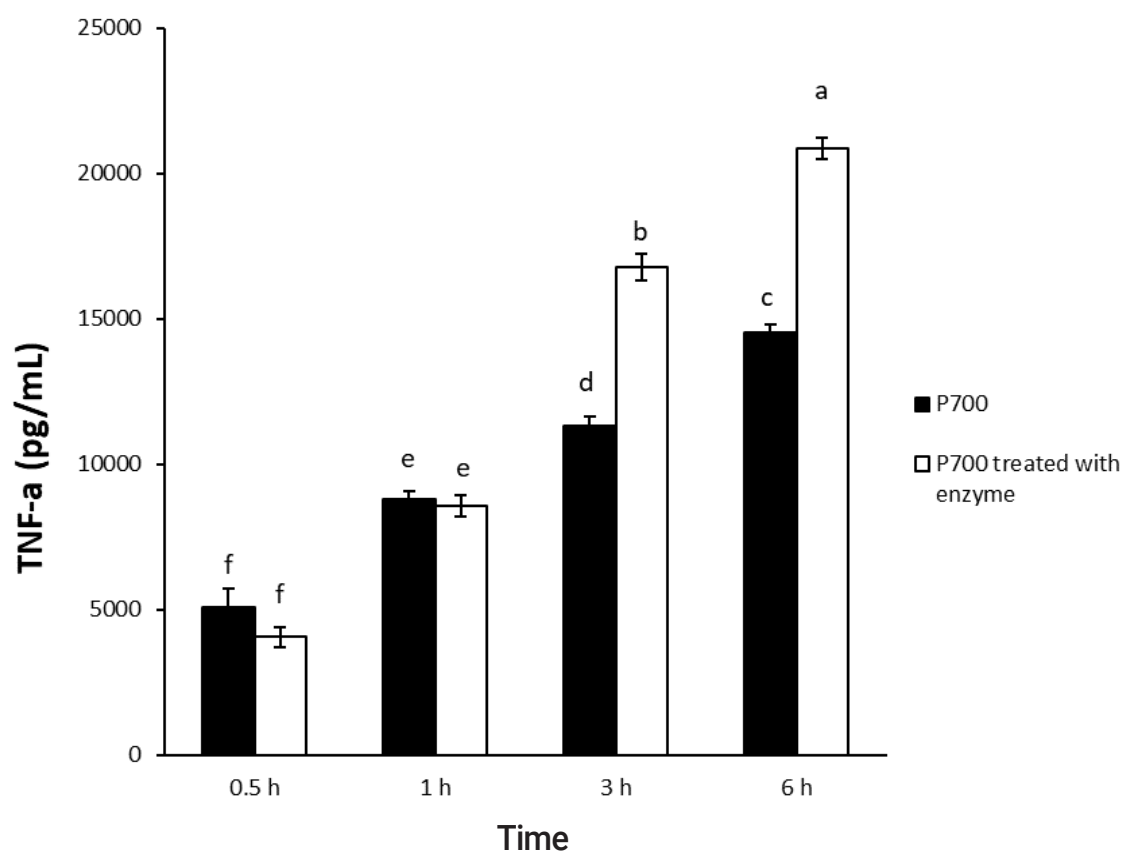

Figure 5. Effect of long-chain inorganic polyphosphate treated with wheat phytase on tumor necrosis factor a (TNF-a) secretion in Raw 264.7 cells during different times. Data are expressed as the mean and standard error from three experiments. ${ }^{\text {a-f }}$ Means lacking common superscripts differ significantly $(p<0.05)$. 


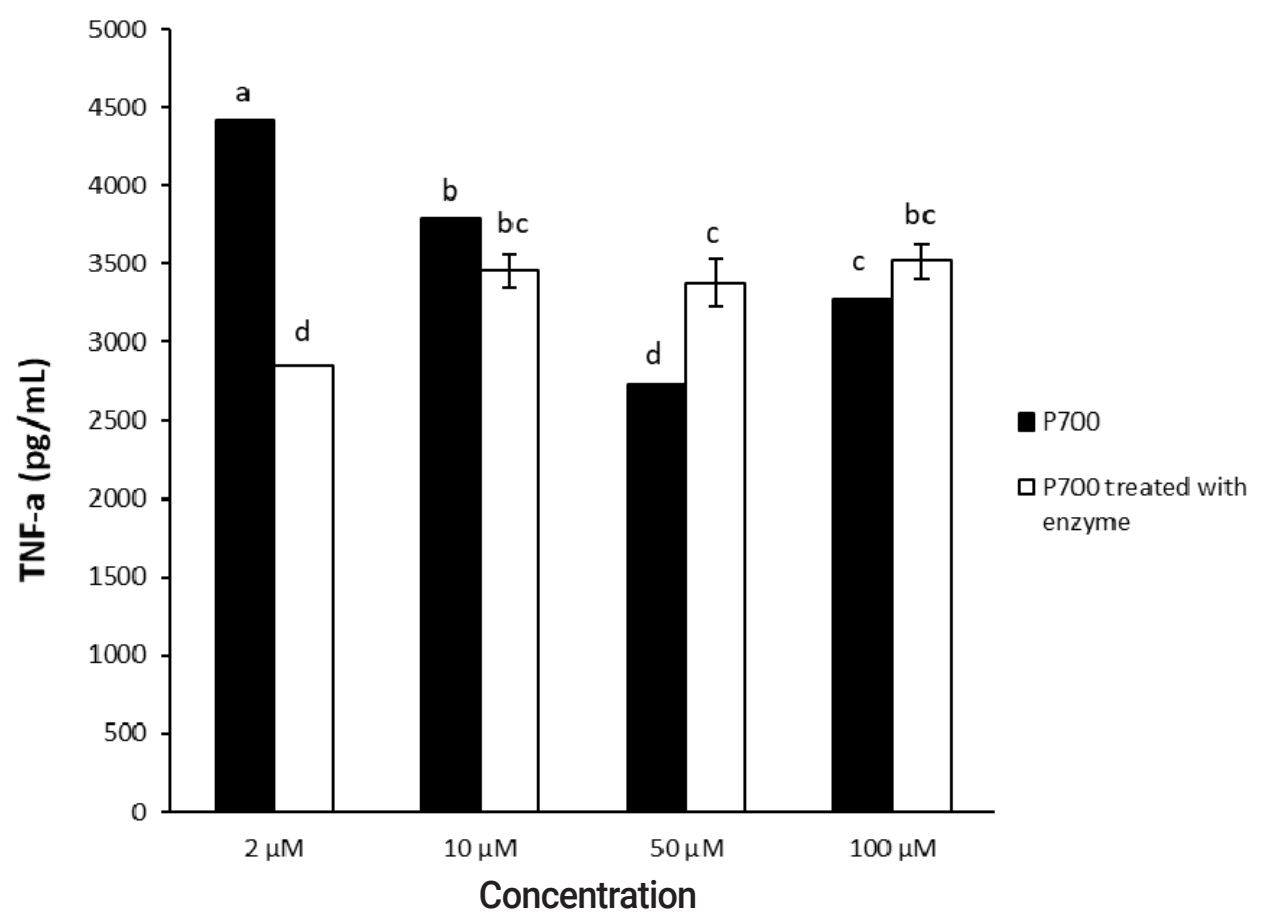

Figure 6. Effect of various concentrations of long-chain inorganic polyphosphate treated with wheat phytase on tumor necrosis factor a (TNF-a) secretion in Raw 264.7 cells. Data are expressed as the mean and standard error from three experiments. ${ }^{a-d}$ Means lacking common superscripts differ significantly $(p<0.05)$.

tion of neutrophils, mast cells, and natural killer cells involved in inflammatory responses [19]. In this study, P700 with added wheat phytase stimulated more NO release than did intact P700. A typical immune activity of macrophages is phagocytosis, the main process that removes pathogenic microorganisms and wastes from the blood or tissue fluid at phagocytes, such as macrophages or polymorphonuclear leukocyte [20]. Phytase-treated P700 increased the phagocytosis in macrophages by dephosphorylating polyP to inorganic phosphate. In recent years, several studies on the interaction between macrophages and phosphate have suggested that phosphates, such as tris-(1,3-dichloro-2-propyl)-phosphate and basic calcium phosphate, increase the intracellular reactive oxygen species level in macrophages and promote macrophage polarization, respectively [21,22]. In addition, sphingosine 1-phosphate (S1P)/S1P receptors (S1PRs) promoted polarization of BMMs (monocyte/macrophages derived from mouse bone marrow) [23]. Presumably, the release of inorganic phosphate from $\mathrm{P} 700$ by wheat phytase might stimulate the production of $\mathrm{NO}$ and phagocytosis in macrophages. Macrophages secrete various inflammatory cytokines, a type of extracellular signaling molecule that regulates overall innate and adaptive immunity actions, such as infection, inflammation, and $\mathrm{B}$ and $\mathrm{T}$ cell differentiation and proliferation that are caused by pathogenic microorganisms or viruses [24]. Among these cytokines, pro-inflammatory cytokine TNF- $\alpha$ promotes immune response early in the immune response [25]. The TNF- $\alpha$ secretion of macrophages is modulated by probiotics like lactobacillus [26]. The secretion of this cytokine in macrophages is also stimulated by some kinds of phosphatase. Previous studies have shown that protein tyrosine phosphatase- $1 \mathrm{~B}$ regulates the inflammatory cytokines, such as interleukin-1 $\beta$ (IL-1 $\beta$ ), IL-6, and TNF- $\alpha$ in Raw 264.7 cells [27]. Furthermore, protein tyrosine phosphatase receptor type $\mathrm{O}$, which belongs to the phosphor tyrosine phosphatases family, promoted the inflammatory response in macrophages [28]. Like these phosphatases, P700 treated with wheat phytase increased the immune response of macrophages induced by TNF- $\alpha$. Therefore, in this study, wheat phytase facilitated the production of proinflammatory cytokine and might stimulate the immune response of macrophages.

In conclusion, wheat phytase could be an immunological modulator in the feed industry, because it increased the NO production, phagocytosis, and cytokine secretion of macrophages. Thus, it can enable macrophages to improve the health and welfare of the host livestock. There are some studies showing that phytase increases the number of lymphocytes and antibodies of a broiler, so attention is needed for its role as an immunological regulator beyond its typical role as a digestive assistant [29]. However, there are various factors that can influence the activity of phytase, such as the optimal $\mathrm{pH}$ range, phytase resistance, animal species, and age [1]. The information available on the catalytic properties of polyP 
hydrolase is very limited. Therefore, this study of wheat phytase as a new regulator of polyP-mediated inflammatory response is very important considering the academic and industrial implications and the ripple effects of the results of the research.

\section{CONFLICT OF INTEREST}

We certify that there is no conflict of interest with any financial organization regarding the material discussed in the manuscript.

\section{ACKNOWLEDGMENTS}

This research was supported by the Basic Science Research Program through the National Research Foundation of Korea (NRF) funded by the Ministry of Education (2017R1D1A1B 03028091).

\section{REFERENCES}

1. Dersjant-Li Y, Awati A, Schulze H, Partridge G. Phytase in non-ruminant animal nutrition: a critical review on phytase activities in the gastrointestinal tract and influencing factors. J Sci Food Agric 2015;95:878-96. https://doi.org/10.1002/ jsfa.6998

2. Dionisio G, Holm PB, Brinch-Pedersen H. Wheat (Triticum aestivum $\mathrm{L}$.) and barley (Hordeum vulgare $\mathrm{L}$.) multiple inositol polyphosphate phosphatases (MINPPs) are phytases expressed during grain filling and germination. Plant Biotechnol J 2007; 5:325-38. https://doi.org/10.1111/j.1467-7652.2007.00244.x

3. Kilaparty SP, Singh A, Baltosser WH, Ali N. Computational analysis reveals a successive adaptation of multiple inositol polyphosphate phosphatase 1 in higher organisms through evolution. Evol Bioinform 2014;10:239-50. https://doi.org/ 10.4137/EBO.S18948

4. An J, Cho J. Catalytic properties of wheat phytase that favorably degrades long-chain inorganic polyphosphate. AsianAustralas J Anim Sci 2020;33:127-31. https://doi.org/10. 5713/ajas. 19.0047

5. Brown MRW, Kornberg A. Inorganic polyphosphate in the origin and survival of species. Proc Natl Acad Sci USA 2004; 101:16085-7. https://doi.org/10.1073/pnas.0406909101

6. Brown MRW, Kornberg A. The long and short of it - polyphosphate, PPK and bacterial survival. Trends Biochem Sci 2008; 33:284-90. https://doi.org/10.1016/j.tibs.2008.04.005

7. Pokhrel A, Lingo JC, Wolschendorf F, Gray MJ. Assaying for inorganic polyphosphate in bacteria. J Vis Exp 2019;143: e58818. https://doi.org/10.3791/58818

8. Kim KS, Rao NN, Fraley CD, Kornberg A. Inorganic polyphosphate is essential for long-term survival and virulence factors in Shigella and Salmonella spp. Proc Natl Acad Sci
USA 2002;99:7675-80. https://doi.org/10.1073/pnas.1122 10499

9. Varas MA, Riquelme-Barrios S, Valenzuela C, et al. Inorganic polyphosphate is essential for Salmonella Typhimurium virulence and survival in Dictyostelium discoideum. Front Cell Infect Microbiol 2018;8:8. https://doi.org/10.3389/fcimb. 2018.00008

10. Kumar A, Gangaiah D, Torrelles JB, Rajashekara G. Polyphosphate and associated enzymes as global regulators of stress response and virulence in Campylobacter jejuni. World J Gastroenterol 2016;22:7402-14. https://doi.org/10.3748/wjg. v22.i33.7402

11.Lorenz B, Schroder HC. Mammalian intestinal alkaline phosphatase acts as highly active exopolyphosphatase. Biochim Biophys Acta Protein Stuct Mol Enzymol 2001;1547:254-61. https://doi.org/10.1016/S0167-4838(01)00193-5

12.Dinarvand P, Hassanian SM, Qureshi SH, et al. Polyphosphate amplifies proinflammatory responses of nuclear proteins through interaction with receptor for advanced glycation end products and P2Y1 purinergic receptor. Blood 2014;123:93545. https://doi.org/10.1182/blood-2013-09-529602

13. Hassanian SM, Avan A, Ardeshirylajimi A. Inorganic polyphosphate: a key modulator of inflammation. J Thromb Haemost 2017;15:213-8. https://doi.org/10.1111/jth.13580

14. Hassanian SM, Dinarvand P, Smith SA, Rezaie AR. Inorganic polyphosphate elicits pro-inflammatory responses through activation of the mammalian target of rapamycin complexes 1 and 2 in vascular endothelial cells. J Thromb Haemost 2015; 13:860-71. https://doi.org/10.1111/jth.12899

15.Zhu J, Zhao L, Guo H, Jiang L, Ren F. Immunomodulatory effects of novel bifidobacterium and lactobacillus strains on murine macrophage cells. Afr J Microbiol Res 2011;5:8-15. https://doi.org/10.5897/AJMR10.589

16.Song G, Du Q. Isolation of a polysaccharide with anticancer activity from Auricularia polytricha using high-speed countercurrent chromatography with an aqueous two-phase system. J Chromatogr A 2010;1217:5930-4. https://doi.org/10.1016/ j.chroma.2010.07.036

17. Yan F, Polk DB. Probiotics and immune health. Curr Opin Gastroenterol 2011;27:496-501. https://doi.org/10.1097/ MOG.0b013e32834baa4d

18. Triantafillidis JK, Triantafyllidi A, Vagianos C, Papalois A. Favorable results from the use of herbal and plant products in inflammatory bowel disease: evidence from experimental animal studies. Ann Gastroenterol 2016;29:268-81. https:// doi.org/10.20524/aog.2016.0059

19. Klimp AH, de Vries EGE, Scherphof GL, Daemen T. A potential role of macrophage activation in the treatment of cancer. Crit Rev Oncol Hematol 2002;44:143-61. https://doi.org/10. 1016/S1040-8428(01)00203-7

20.Liu CF, Tseng KC, Chiang SS, Lee BH, Hsu WH, Pan TM. Immunomodulatory and antioxidant potential of Lactobacillus 
exopolysaccharides. J Sci Food Agric 2011;91:2284-91. https:// doi.org/10.1002/jsfa.4456

21.Zhang W, Wang R, Giesy JP, Li Y, Wang P. Tris (1,3-dichloro2-propyl) phosphate treatment induces DNA damage, cell cycle arrest and apoptosis in murine RAW264.7 macrophages. J Toxicol Sci 2019;44:133-44. https://doi.org/10.2131/jts.44. 134

22. Corr EM, Cunningham CC, Helbert L, McCarthy GM, Dunne A. Osteoarthritis-associated basic calcium phosphate crystals activate membrane proximal kinases in human innate immune cells. Arthritis Res Ther 2017;19:23. https://doi.org/10.1186/ s13075-017-1225-0

23. Yang J, Yang L, Tian L, Ji X, Yang L, Li L. Sphingosine 1-phosphate (S1P)/S1P receptor2/3 axis promotes inflammatory M1 polarization of bone marrow-derived monocyte/macrophage via G(a)i/o/PI3K/JNK pathway. Cell Physiol Biochem 2018; 49:1677-93. https://doi.org/10.1159/000493611

24.Delcenserie V, Martel D, Lamoureux M, Amiot J, Boutin Y, Roy D. Immunomodulatory effects of probiotics in the intestinal tract. Curr Issues Mol Biol 2008;10:37-54. http://doi. org/10.21775/cimb.010.037
25.Mizumachi K, Aoki R, Ohmori H, Saeki M, Kawashima T. Effect of fermented liquid diet prepared with Lactobacillus plantarum LQ80 on the immune response in weaning pigs. Animal 2009;3:670-6. https://doi.org/10.1017/S17517311 09003978

26. Morita H, He F, Fuse T, et al. Cytokine production by the murine macrophage cell line J774.1 after exposure to lactobacilli. Biosci Biotechnol Biochem 2002;66:1963-6. https:// doi.org/10.1271/bbb.66.1963

27. Yang L, Sun Y, Liu Y, et al. PTP1B promotes macrophage activation by regulating the NF- $\mathrm{BB}$ pathway in alcoholic liver injury. Toxicol Lett 2020;319:11-21. https://doi.org/10. 1016/j.toxlet.2019.11.001

28. Zhao J, Yan S, Zhu X, Bai W, Li J, Liang C. PTPRO exaggerates inflammation in ulcerative colitis through TLR4/NF- $\mathrm{kB}$ pathway. J Cell Biochem 2020;121:1061-71. https://doi.org/10. 1002/jcb.29343

29.Liu N, Ru YJ, Cowieson AJ, Li FD, Cheng XCH. Effects of phytate and phytase on the performance and immune function of broilers fed nutritionally marginal diets. Poult Sci 2008;87:1105-11. https://doi.org/10.3382/ps.2007-00517 